\title{
Local production of corticotropin releasing hormone is increased in experimental intestinal inflammation in rats
}

\author{
E A F van Tol, P Petrusz, P K Lund, M Yamauchi, R B Sartor
}

\begin{abstract}
Background/Aims-Corticotropin releasing hormone (CRH) suppresses immunological functions via stimulation of the pituitary-adrenal axis, but is also found in peripheral tissues. Peripheral proinflammatory activity of $\mathrm{CRH}$ is suggested by increased tissue concentrations in arthritis and in vitro immunostimulatory effects. This study evaluated intestinal CRH concentrations, immunolocalisation, and synthesis in chronic enterocolitis and investigated in vitro responsiveness of lamina propria mononuclear cells to CRH.
\end{abstract}

Methods-Chronic granulomatous enterocolitis was induced by intramural injection of peptidoglycan-polysaccharide polymers in the ileocaecal region of Lewis rats. CRH protein was measured in caecal specimens by immunohistochemistry and radioimmunoassay and caecal CRH mRNA expression was analysed by reverse transcriptase polymerase chain reaction. Results-In the chronically inflamed caecum abundant immunoreactive $\mathrm{CRH}$ was found in inflammatory cells, mesenchymal cells, as well as in myenteric plexi. In contrast, only a few CRH containing cells were detected in normal and HSA injected control caecums. Moreover, caecal CRH protein levels were increased during chronic enterocolitis. Local CRH synthesis as indicated by mRNA expression was considerably increased in chronic enterocolitis whereas it was undetectable or low in uninflamed caecum. In addition, CRH stimulated in vitro proliferation of lamina propria mononuclear cells and inhibited mitogen induced proliferation.

Conclusion-Increased CRH protein and mRNA expression in chronic enterocolitis and responsiveness of intestinal mononuclear cells to CRH indicate an immunomodulatory role for locally produced CRH in intestinal inflammation.

(Gut 1996; 39: 385-392)

Keywords: corticotropin releasing hormone, experimental enterocolitis, Lewis rats.

Regulation of immune reactivity to mucosal or systemic noxious stimuli without inducing destructive chronic inflammation requires balanced interaction between the nervous, endocrine, and immune systems. The immune system shares bi-directional communication pathways with both the nervous and endocrine networks. ${ }^{1-3}$ For example, peripheral and mucosal lymphoid organs have direct neuropeptidergic innervation. ${ }^{45}$ Not only can immune cells be found in intimate association with nerve fibres, ${ }^{6}$ they also have specific highaffinity receptors for neuropeptides and hormones. ${ }^{7}$ Furthermore, hormones and neuropeptides endogenous to the gastrointestinal tract modulate the activity of immune cells isolated from gut associated lymphoid tissues and the intestinal lamina propria. ${ }^{8} 9$ A variety of neuropeptides can be synthesised by immune cells suggesting that neuropeptides have autocrine/paracrine actions on immune cells or that the immune system shares functional homology with the neuroendocrine system. ${ }^{310}$ Together, these findings indicate that neuropeptides and hormones can regulate the activity of immune cells in endocrine, paracrine, and possibly autocrine fashions similar to immunoregulatory activities of cytokines.

Local production of corticotropin releasing hormone (CRH) has been associated with peripheral inflammation ${ }^{11-13}$ suggesting that this neuropeptide may have a proinflammatory role when produced outside the brain. This is in sharp contrast with its well known immunosuppressive role as the key regulator of the hypothalamus-pituitary-adrenal axis. At present it is firmly established that the production of CRH is not confined to the hypothalamus. $\mathrm{CRH}$ has been demonstrated in the normal spinal cord, lung, liver, spleen, stomach, pancreas, ovaries, placenta, endometrium, and intestine with differential distribution among mammalian species. ${ }^{14-21}$ More importantly, in vitro studies almost unequivocally point to an immunostimulatory effect of CRH. CRH stimulates cytokine secretion, ${ }^{22-24}$ increases the expression of interleukin 2 receptors on $\mathrm{T}$ cells, ${ }^{25}$ increases the FMLP induced production of reactive oxygen metabolites by macrophages, ${ }^{26}$ stimulates both spontaneous and ConA induced splenocyte proliferation, ${ }^{25} 27$ (van Tol unpublished observations), and stimulates natural killer cell activity. ${ }^{28}$

In contrast, not much is known about the role of local production of $\mathrm{CRH}$ in the pathogenesis of tissue inflammation although increased CRH protein or mRNA expression, or both, are found in human arthritis and rat models of bacterial cell wall induced arthritis and carrageenin induced granulomatous exudative inflammation. ${ }^{11-13}$ Direct evidence for the pivotal peripheral role of $\mathrm{CRH}$ in 
experimental inflammation came from the carrageenin model in which systemic immunoneutralisation of $\mathrm{CRH}$ resulted in marked suppression of inflammation. ${ }^{11}$

In this study we investigated the presence and local production of CRH in a model of chronic enterocolitis. Subserosal intramural injection of poorly degradable, purified peptidoglycan-polysaccharide from group A Streptococcus pyogenes (PG-APS) in the caecum and distal ileum induces biphasic inflammation in genetically susceptible Lewis rats. ${ }^{29}$ Granulomatous enterocolitis with associated arthritis, hepatic granulomas, anaemia, and leucocytosis spontaneously develops approximately two weeks after a single injection of PG-APS. ${ }^{29} 30$ Transmural granulomatous inflammation with extensive fibrosis is characteristic for the chronic phase of enterocolitis that persists for at least 16 weeks in this model.

In this and other experimental models of inflammation Lewis rats have been shown to be a highly susceptible strain. ${ }^{29-31}$ Part of this genetic susceptibility in Lewis rats underlying the development of exaggerated inflammation may involve a blunted hypothalamic $\mathrm{CRH}$ response to bacterial cell wall products, cytokines, and neurotransmitters. ${ }^{31-33}$

Here we hypothesise that Lewis rats have increased peripheral CRH production associated with chronic inflammation, and that local proinflammatory effects of $\mathrm{CRH}$ contribute to the development or perpetuation of chronic intestinal inflammation, or both, in a susceptible host.

\section{Methods}

\section{Bacterial cell wall preparation}

Sterile PG-APS polymers with the molecular weight of $5 \times 10^{6} \mathrm{kDa}$ to $5 \times 10^{8} \mathrm{kDa}$ were prepared from group A, type 3 strain D58 Streptococcus pyogenes as described previously ${ }^{34}$ and provided by Dr J Schwab and R Brown, Department of Immunology and Microbiology, University of North Carolina at Chapel Hill. The preparation was sonicated to disperse aggregates immediately before use and the final concentration was calculated based on rhamnose content. ${ }^{35}$

\section{Induction of enterocolitis}

Female, inbred specific pathogen free (SPF) Lewis rats (140-160 g) were obtained from Charles Rivers Breeding Laboratories (Raleigh, NC) and kept in a SPF facility with free access to food and water. All experiments were performed in compliance with the criteria outlined by the University of North Carolina Institutional Animal Care and Use Committee. Animals were anaesthetised with $1.3 \mathrm{ml} / \mathrm{kg}$ body weight Innovar (Pitman-Moore Co, Washington Crossing, NJ), the intestines were exposed by aseptic laparotomy and subserosally injected with PG-APS $(12.5 \mu \mathrm{g}$ rhamnose/g body weight) or the same dose of human serum albumin (HSA, Baxter Health Care) as described previously. ${ }^{29} \mathrm{~A}$ total volume of $0.45 \mathrm{ml}$ was divided over seven injection sites including the junction of the mesentery and the distal ileum (two injections $\times 0.05 \mathrm{ml}$ ), two distal ileal Peyers' patches $(2 \times 0.05 \mathrm{ml})$, the caecal tip (lymphoid aggregate, $0.05 \mathrm{ml}$ ), and the mid and upper caecum (two sites $\times 0 \cdot 1$ $\mathrm{ml}$ ). Rats in the acute inflammation group were killed 48 hours after injections whereas rats in the chronic inflammation group were killed 29, 33 , or 85 days after injections. All animals were killed by overdose inhalation of $\mathrm{CO}_{2}$. Gross inflammation was scored by a single blinded observer according to criteria developed and validated for this model. ${ }^{29}$ Values of $0-4$ were assigned to the number of caecal nodules, contraction of mesentery, number and severity of adhesions, and caecal wall thickening, with a maximal possible summed gross gut score (GGS) of 16.

\section{Tissue collection and processing}

Caecal tissue samples were snap frozen in liquid nitrogen and stored at $-80^{\circ} \mathrm{C}$ for isolation of RNA and protein. The caecal tip was oriented in a plastic container with OCT (Miles Inc, Elkhart, IN), snap frozen in isopentane, and stored at $-80^{\circ} \mathrm{C}$ for immunohistochemistry studies. Total RNA was isolated from samples of caecal tissue from PGAPS, HSA injected, and normal Lewis rats using a standard procedure. ${ }^{29}$ RNA concentration and purity was quantified by absorbance at $260 \mathrm{~nm}$ and $A 260 / 280$ ratios. The integrity of RNA was verified by electrophoresis of samples in $1.4 \%$ agarose gels containing ethidium bromide.

\section{Immunohistochemistry}

Indirect immunohistochemical staining for rat CRH was done using the avidin-biotin peroxidase complex (ABC) kit (Vectastain, Vector Lab, Burlingame, CA). Sections of brain from a longterm adrenalectomised Lewis rat were used as controls because immunostaining of CRH is increased in the brain due to lack of corticosteroid feedback inhibition. Ten $\mu \mathrm{m}$ frozen sections were cut from the brain of the adrenalectomised rat and from fresh frozen caecal tips collected from PG-APS or HSA injected or normal Lewis rats. Sections were post-fixed in $4 \%$ paraformaldehyde with $10 \%$ sucrose for five minutes and washed in phosphate buffered saline (PBS). All incubations were performed at room temperature unless otherwise stated. Sections were treated with methanol and $0.6 \% \mathrm{H}_{2} \mathrm{O}_{2}$ for 45 minutes to exhaust endogenous peroxidase activity, incubated with $2 \%$ normal goat blocking serum in PBS for 10 minutes, then incubated overnight with either the primary rabbit antirat CRH antiserum (1:500-1:1000 dilutions, Peninsula Lab, Belmont, CA), normal rabbit serum, rabbit IgG, or $2 \%$ normal goat serum at $4^{\circ} \mathrm{C}$. The sections were washed in PBS, and incubated with $2 \%$ normal goat serum blocking solution for 10 minutes, followed by incubation with biotinylated goat antirabbit IgG (1:400 dilution, Organon Teknika, 
Durham, NC) for 45 minutes, washed in PBS, and incubated with the $A$ and $B$ components (1:400) of the Vectastain kit for 45 minutes. Coloured precipitation product was developed by immersing sections in $0.05 \mathrm{M}$ TRIS-HCL buffer $\mathrm{pH} 7 \cdot 4$ containing $0.075 \% 3$,3 diaminobenzidine tetrahydrochloride (DAB, Aldrich Chemical, Milwaukee, Wi) and $0.02 \% \mathrm{H}_{2} \mathrm{O}_{2}$. After washing in TRIS buffer and PBS, the staining was intensified with evaporating $\mathrm{OsO}_{4}$ $\left(2 \%\right.$ in $\left.\mathrm{dH}_{2} \mathrm{O}\right)$ for five minutes, washed in PBS, counterstained with $0.05 \%$ toluidine blue in $30 \%$ ethyl alcohol, dehydrated through graded alcohols and xylene, mounted with Permount (Fisher Scientific, Pittsburgh, PA), and cover slipped.

\section{Radioimmunoassay (RIA) and non-collagen protein determinations}

For extraction of immunoreactive $\mathrm{CRH}$ (irCRH), total protein, and collagen the tissues were homogenised in $1 \mathrm{ml}$ of $0 \cdot 1 \mathrm{~N}$ acetic acid for 30 seconds using a Tissuemizer. The homogenates were boiled for five minutes, cooled on ice for five minutes followed by centrifugation for 10 minutes at $2000 \times g$. The supernatants were collected and stored at $-20^{\circ} \mathrm{C}$. $\mathrm{CRH}$ concentrations were determined using a specific radioimmunoassay for rat/human CRH (Peninsula Lab, Belmont, CA). Total protein concentrations in the supernatants were determined using a microprotein assay (Sigma, St Louis, MO).

\section{Collagen measurements}

An $100 \mu l$ aliquot of the tissue homogenate was lyophilised and subsequently hydrolysed with $6 \mathrm{~N} \mathrm{HCL}$ in vacuo under $\mathrm{N}_{2}$ at $110^{\circ} \mathrm{C}$ for 22 hours. The hydrolysate was dried by a speed vacuum concentrator, dissolved in distilled water, filtered with $0.22 \mu \mathrm{m}$ membrane, and subjected to amino acid analysis using a Varian 5500 HPLC system. ${ }^{36}$ The relative amount of collagen in the total protein fraction was determined using a value of 100 residues of hydroxyproline per 1000 for a typical fibrillar collagen standard. ${ }^{36}$

\section{$R T-P C R$}

For the reverse transcriptase polymerase chain reaction (RT-PCR) analysis of CRH mRNA, $1 \mu \mathrm{g}$ of total RNA isolated from intestinal tissues and brain controls was reverse transcribed to cDNA using random hexamers in a reaction volume of $50 \mu$ l containing 200 units of Superscript Reverse Transcriptase RNase H- (Gibco BRL, Gaithersburg, MD), $50 \mathrm{mM}$ TRIS-HCL (Gibco), $75 \mathrm{mM}$ KCL (Gibco), 3 $\mathrm{mM} \mathrm{MgCL}$ (Gibco), $10 \mathrm{mM}$ DTT (Gibco), $1 \mathrm{mM}$ dNTP (Perkin Elmer/Applied Biosystems, Foster City, CA), $1 \mu M$ random hexamers (Perkin Elmer), and 0.5 Units $/ \mu 1$ RNase inhibitor (Perkin Elmer). The reaction mixture was incubated for 45 minutes at $45^{\circ} \mathrm{C}$, boiled for five minutes to stop the reaction, cooled on ice for three minutes, and stored at $-20^{\circ} \mathrm{C}$. All PCR reactions were done in a 50 $\mu l$ reaction volume with $1 \mu l$ of the first strand cDNA and $50 \mathrm{mM} \mathrm{KCl}, 20 \mathrm{mM}$ TRIS-HCL, 2.5 $\mu \mathrm{M} \mathrm{MgCL}_{2}, 0.1-0.5 \mu \mathrm{mM}$ dNTPs, $0 \cdot 1-0.25 \mathrm{mM}$ of each antisense and sense primer, and 1.5-2.5 U of Taq polymerase (Perkin Elmer). The primers used for rat CRH were sense 5' CAAGTACGTTGAGAAACTGAAG and antisense 5' CCGAGCAGCGGGACTTCTGT for the first amplification and the same sense primer with antisense 5' GGGCTGCTCCGGTTGCAAG for the seminested primer second amplification run. For the nested primer amplification, $1 \mu$ l of the first PCR product obtained after 35 cycles was diluted 1:250 and used as a template in a fresh reaction mix for a second amplification of 32 cycles. For rat $\beta$-actin ${ }^{12}$ sense 5 ' ACCACAGCTGAGAGGGAAATCG and antisense 5' AGAGGTCTTTACGGATGTCAACG primers were used for 25-30 cycles amplification. All primers were constructed to span an intron to enable assessment of contaminating genomic DNA. Conditions for amplification of rat CRH were denaturation at $95^{\circ} \mathrm{C}$ for five minutes, and amplification cycles, $94^{\circ} \mathrm{C}$ for 45 seconds, $58^{\circ} \mathrm{C}$ for one minute, $72^{\circ} \mathrm{C}$ for 1.5 minutes, and for rat $\beta$-actin $94^{\circ} \mathrm{C}$ for 45 seconds, $60^{\circ} \mathrm{C}$ for one minute, and $72^{\circ} \mathrm{C}$ for 1.5 minutes. Rat brain cDNA was used as a positive control and to optimise amplification conditions for $\mathrm{CRH}$ mRNA. Amplifications without cDNA were run as negative controls. The PCR products were analysed on a $1.5 \%$ agarose TAE gel containing ethidium bromide. The specificity of the amplification product was confirmed by size and by obtaining fragments of predicted size (245 and $62 \mathrm{bp}$ ) after digestion with restriction enzyme BamH1 (Boehringer Mannheim).

\section{Lamina propria mononuclear cell (LPMC)} isolation and in vitro stimulation

LPMC were isolated from ileal tissue from normal Lewis rats. Tissue was washed in calcium and magnesium free Hank's balanced salt solution (CMF-HBSS) with antibiotics. The tissue was cut longitudinally, washed, cut into smaller pieces, and incubated in CMFHBSS with $10 \mathrm{mM}$ DTT (Sigma) and antibiotics for 20 minutes at room temperature.

After washing, the tissue was transferred to prewarmed CMF-HBSS with $0.8 \mathrm{mM}$ ethylenediamine tetraacetic acid (Fischer Scientific, Pittsburgh PA) and additives for four to five sequential incubations. After epithelium depletion the tissue pieces were cut smaller and incubated twice for one hour in RPMI with $10 \%$ FCS, antibiotics, and Dispase grade I $(0.08 \mathrm{mg} / \mathrm{ml}$, Boehringer Mannheim) and DNase grade II $(0.075 \mathrm{mg} / \mathrm{ml}$, Boehringer Mannheim) at $37^{\circ} \mathrm{C}$ on a shaking table. After enzymatic digestion the supernatants were filtered through a mesh (Nitex, Tetko Inc, Elmsford, NY), washed, and mononuclear cells were isolated by density gradient centrifugation (Histopaque, $1.083 \mathrm{~g} / \mathrm{l}$, Sigma). Then the cells were washed, counted, and cultured at $2 \times 10^{6}$ cells $/ \mathrm{ml}$ in $200 \mu \mathrm{l}$ of RPMI supplemented with $10 \%$ FCS, antibiotics and 
synthetic CRH 1-41 (Sigma) or $0.25 \mu \mathrm{g} /$ well ConA (Sigma), or both, in 96 well microtitre plates. The plates were incubated in $5 \% \mathrm{CO}_{2}$ at $37^{\circ} \mathrm{C}$ for 72 hours and cells were pulse labelled with $50 \mu \mathrm{Ci} /$ well ${ }^{3}[\mathrm{H}]$-thymidine (Amersham, Arlington Heights, IL) 18 hours before harvesting and proliferation was measured by liquid scintillation counting.

\section{Statistics}

The data are presented as mean (SEM). Groups were compared using the unpaired two tailed Student's $t$ test. In the proliferation studies dose dependency of the $\mathrm{CRH}$ incubations was analysed by multiple regression analysis followed by the Wilcoxon's signed rank sum test to determine differences between incubations.

\section{Results}

\section{Assessment of inflammation}

To confirm induction of chronic intestinal inflammation, the gross gut score (GGS) for enterocolitis was determined. The score, which includes adhesions, mesenteric contractions, caecal serosal nodules, and caecal wall thickening, was significantly increased during the acute phase after two days $(6.7(0.4)$ (PGAPS) $v 0.3(0.3)$ (HSA), $\mathrm{p}=0.0001)$. This increase in the GGS was even more pronounced during the chronic phases of inflammation, as shown at 26 days $(8.7(0.6)$ (PGAPS) $v 0.6(0.3)$ (HSA), $\mathrm{p}=0.0001)$ and 29 days $(9.3(1.6)$ (PG-APS) $v 1.3(0.7)$ (HSA), $\mathrm{p}=0.0012$ ). The HSA injected control animals showed no signs of active intestinal inflammation at all evaluated time points.

\section{Immunohistochemistry}

Specificity of the anti-CRH serum was tested on sections of the hypothalamus from an adrenalectomised rat. Strong immunoreactive CRH staining was visible in the external layer of the median eminence at the base of the third ventricle (data not shown). Incubations with normal rabbit serum, purified rabbit IgG, as well as normal goat serum were found to be uniformly negative.

The histological appearance of chronic colitis in the caecal tip consists of active granulomatous inflammation in a transmural distribution with extensive fibrosis and evidence of an acute inflammatory component; the submucosa is particularly involved. Abundant presence of CRH immunoreactive cells in the inflamed caecum was observed in chronic enterocolitis 85 days after PG-APS injection (Fig 1A). Anti-CRH immunostaining of caecal tip sections of normal Lewis caecum and of HSA injected control animals at 33 days (Fig 1B), showed a pattern of rarely scattered CRH immunoreactive cells in the submucosa, which might be of neuronal origin and weak staining of plexi in the external muscle layer. No staining was seen in crypt epithelial or neuroendocrine cells. During the chronic phase of inflammation several different cell types were found to contain irCRH. Similar to what was found in the acutely inflamed caecal tissues (two days, data not shown), CRH immunoreactivity was seen in inflammatory cells with a predominant macrophage-like appearance in the chronic phase of PG-APS induced enterocolitis (Fig 1C). CRH was also detected within the myenteric plexi, which appeared to be hyperplastic (Fig 1D). In addition, mesenchymal cells lining the periphery of granulomas were positive for irCRH (Fig 1E). Control incubations of the chronically inflamed caecum with normal rabbit serum, purified rabbit IgG, normal goat serum (Fig $1 F$ ) as well as serial dilutions of the primary $\mathrm{CRH}$ antiserum confirmed specificity of the immunostaining for CRH in gut tissue and the absence of endogenous peroxidase activity.

\section{Tissue concentrations of $C R H$ by} radioimmunoassay

Whole caecal tissue CRH concentrations were significantly increased in the chronic phase of inflammation in PG-APS-injected rats as detected by specific RIA (Fig 2A). Smaller amounts of irCRH could also be detected in caecal tissues of HSA injected control animals. Because the increase in irCRH in chronically inflamed caecum is accompanied by a relatively large increase in the total protein content per gram of wet tissue due to the inflammation, $\mathrm{CRH}$ contents were normalised based on the amount of protein extracted (Fig 2B). In this model of granulomatous enterocolitis however, there is abundant deposition of collagen in the chronic phase of inflammation as revealed by Masson's trichrome staining. ${ }^{30}$ Based on amino acid analysis it was also determined that the collagen fraction comprised a significantly larger proportion of the total caecal protein content in the PG-APS injected group compared with HSA injected control animals $(25 \%$ $v 8 \%, \mathrm{p}<0.05)$. Adjusting the tissue concentration of $\mathrm{CRH}$ based on non-collagenous protein demonstrated a $2 \cdot 2$-fold increase in the mean concentration of irCRH in chronically inflamed tissues compared with the HSA injected control caecal tissue (Fig 2C).

\section{$R T-P C R$ analysis}

We were unable to detect CRH mRNA in caecal tissue samples from PG-APS or HSA injected Lewis rats by northern blot hybridisation using a cDNA probe (data not shown). However, we were able to detect CRH mRNA, which is constitutively expressed in the hypothalamus, in normal Lewis rat brain samples by this method. Therefore we used RT-PCR to detect the relatively low transcript levels of intestinal CRH mRNA. The RT-PCR amplification conditions using a semi-nested primer amplification technique were optimised using the normal Lewis rat brain as a positive control and were used to evaluate CRH mRNA expression during different phases of chronic inflammation in the caecum. This semiquantitative assessment of CRH mRNA 

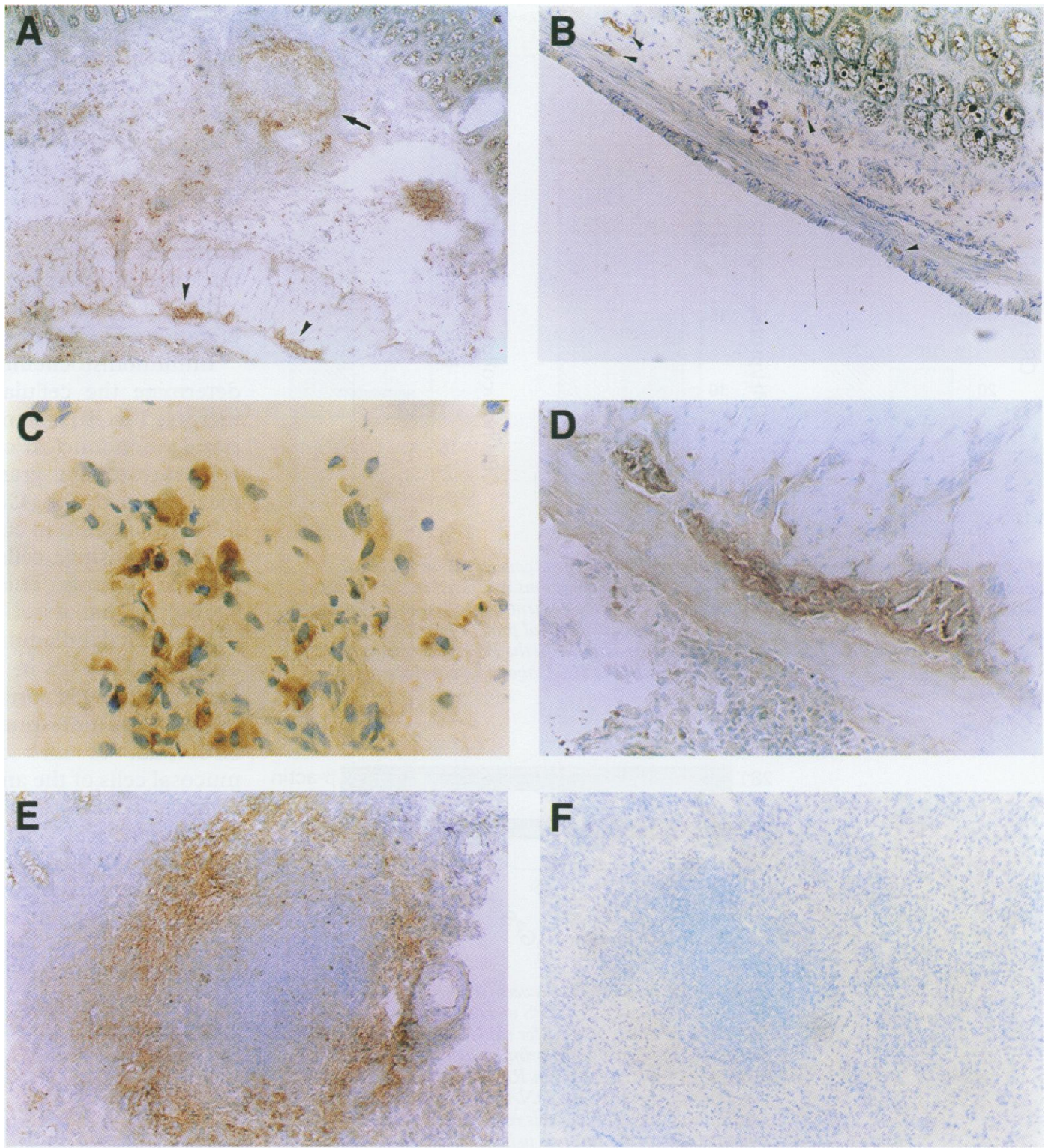

Figure 1: Immunohistochemical staining for $C R H$ in caecal tissues derived from Lewis rats after intramural injections of $P G-A P S, 85$ days $(A, C-F)$ or $H S A, 33$ days $(B)$. CRH immunoreactivity is visualised in inflammatory and mesenchymal cells in the submucosa, particularly surrounding a granuloma (arrow) and in nervous tissue between the hypertrophic external muscle layers (arrowhead) ( $A$, original magnification $\times 40)$. Only a few CRH immunoreactive cells (arrows), possibly of nervous tissue origin, are found in control tissues 33 days after HSA injection (B, original magnification $\times 100)$. CRH containing macrophage-like cells are found in focal areas of mononuclear cellular infiltrate during chronic inflammation (C, original magnification $\times 400)$. CRH immunoreactivity is also present within the myenteric plexus $(D$, original magnification $\times 200)$ and in mesenchymal cells comprising the peripheral rim of a submucosal granuloma $(E$, original magnification $\times 100)$. Negative staining was obtained in control incubations of the same $P G-A P S$ induced chronically inflamed caecal specimen using normal goat serum $(F$, original magnification $\times 100)$.

expression was done by normalising for constitutive $\beta$-actin mRNA levels in each individual sample. Although this does not yield exact data on the fold increase of mRNA message it clearly showed high CRH mRNA expression at all time points during chronic caecal inflammation at 29, 33, and 85 days after PG-APS injection (Fig 3). In contrast, the CRH mRNA message was undetectable or in some cases very low in uninjected or control HSA injected caecal tissues compared with the inflamed tissue samples.

\section{Proliferation studies}

CRH stimulated the proliferation of LPMC isolated from normal Lewis rat ileum in a dose dependent fashion (Fig 4A). Incubation of the cells with ConA $(0.25 \mu \mathrm{g} /$ well $)$ stimulated pro- liferation to a similar extent as was obtained with the higher concentration of $\mathrm{CRH}$ in the non-mitogenic stimulation experiment (Fig 4B). However, co-incubation of ConA stimulated cells with different concentrations of $\mathrm{CRH}$ inhibited proliferation of LPMC (Fig 4B).

\section{Discussion}

It is now firmly established that CRH is also present outside the brain in peripheral tissues and immune cells. This study shows increased local CRH synthesis during PG-APS induced chronic intestinal inflammation. Increased concentrations of irCRH were detected by radioimmunoassay in the chronically inflamed caecum of Lewis rats compared with low constitutive values in HSA injected control animals. Tissue $\mathrm{CRH}$ concentrations were 

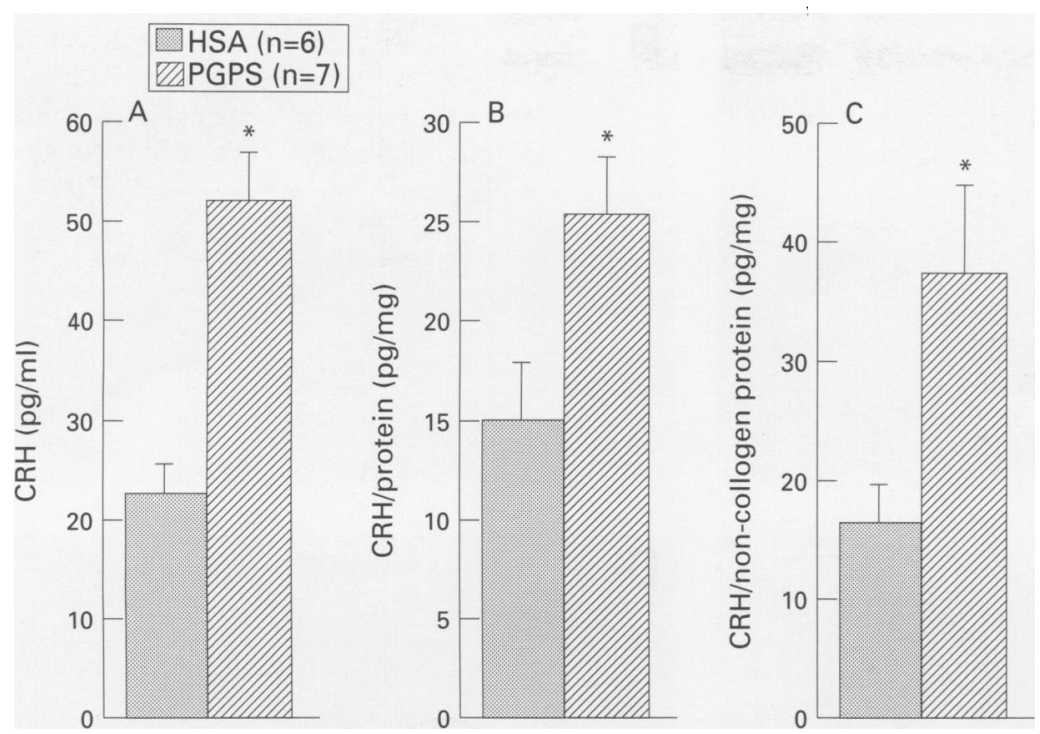

Figure 2: Radioimmunoassay determinations of CRH tissue concentration in caecal homogenates 29 days after PG-APS or control HSA injections measured in the extracted tissue supernatants $(A)$, normalised for the total protein content in the extracts $(B)$ as well as corrected for the proportion of collagen in the extracted total protein fraction (C). Significantly increased CRH concentrations were detected in the PG-APS induced chronically inflamed caecal tissues compared with the HSA injected control specimens, ${ }^{\star} p<0.05$.

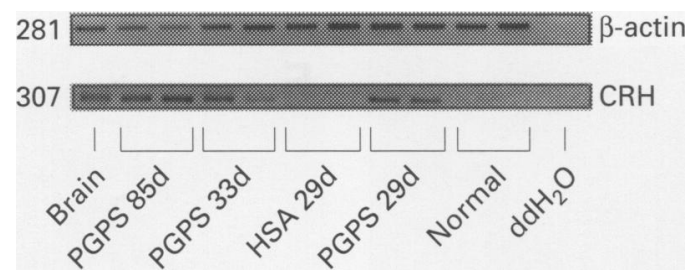

Figure 3: PCR analysis of reverse transcribed $R N A$ isolated from caecal tissue of $P G-A P S$ or $H S A$ injected and normal from caecal tissue of $P G-A P S$ or $H S A$ injected and normal
Lewis rats. Primers specific for rat $C R H$ generated a 307 bp fragment after semi-nested primer amplification. $c D N A$ transcribed from Lewis brain RNA samples and PCR reaction samples without $c D N A$ added were included as positive and negative controls respectively. Control amplification of the samples using primers specific for rat $\beta$ confirmed equal loading. The data have been consistently reproduced in more than 10 separate assays of randomly selected chronically inflamed and control tissues from rats in other chronic phase experiments.
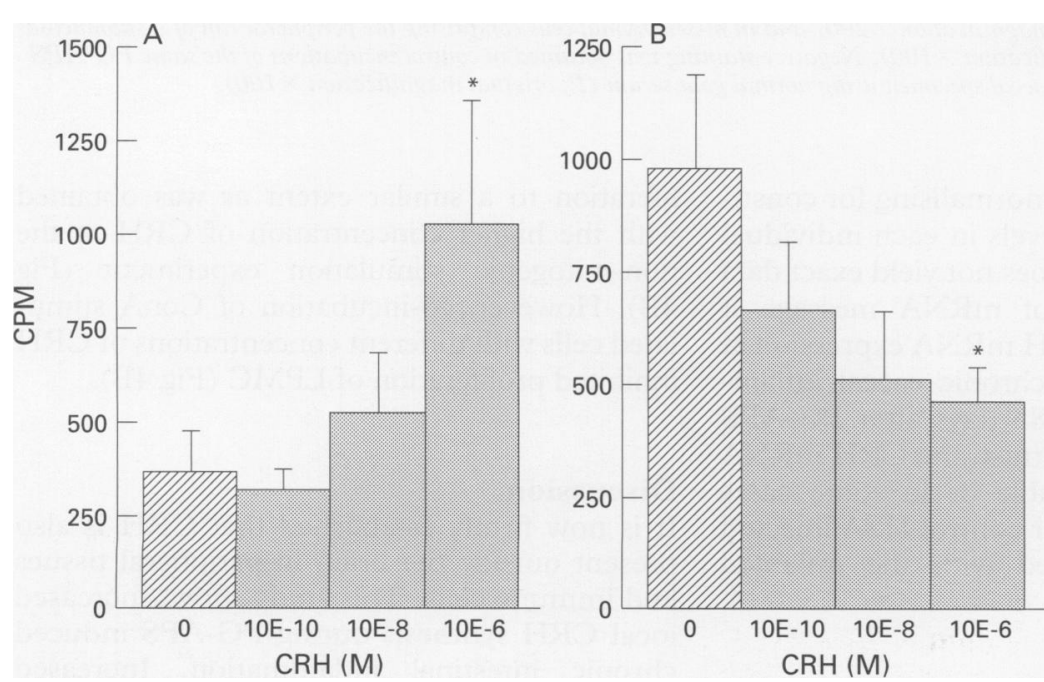

Figure 4: Effect of synthetic CRH on proliferation of LPMC isolated from normal Lewis rat ileum. Spontaneous $(A)$ or ConA induced $(B)$ proliferation after 72 hours LPMC culture presented as the mean cpm of ${ }^{3}[H]$-thymidine incorporation. Dose dependency of $C R H$ induced stimulation of spontaneous proliferation $(A, p=0.018)$ or inhibition of ConA stimulated proliferation $(B, p=0 \cdot 019)$ was analysed by multiple regression with $C R H$ as an independent variable. $n=6,{ }^{*} p<0.05$ compared with control media incubation. measured in total caecal homogenates and do not accurately reflect local concentrations, which may reach substantially higher values in focal areas of inflammation or near nerve endings. Although local $\mathrm{CRH}$ production cannot be accurately measured, it is quite likely that some intestinal inflammatory cells are exposed to $\mathrm{CRH}$ concentrations capable of modulating their activity. The ability of intestinal immune cells to respond to $\mathrm{CRH}$ is indicated by dose dependent effects on proliferation of LPMC.

Immunohistochemistry was performed to determine the cellular source of location of increased irCRH demonstrated by RIA. Infiltrating mononuclear cells, (myo)fibroblast-like cells surrounding granulomas, and myenteric plexi stained for $\mathrm{CRH}$ in the chronically inflamed caecum in contrast with only sparsely scattered positive cells in the normal or HSA injected controls. This staining pattern is very similar to that described in other models of experimental inflammation in rats. ${ }^{11} 12$ However, our findings in the rat intestine do not match the few reports of CRH in the normal human gastrointestinal tract. Nieuwenhuijzen Kruseman et $a l^{14}$ demonstrated $\mathrm{CRH}$ in mucosal cells of the antrum and small intestine whereas Kawahito et al ${ }^{19}$ found that irCRH colocalised with 5-HT in normal colonic enterochromaffin cells, and found abundant CRH protein in colonic lamina propria macrophages of patients with active ulcerative colitis. ${ }^{37}$ We also found irCRH staining in macrophage-like cells in the inflamed caecum but not in normal or inflamed rat colonic epithelial cells. The reason for these species differences is unclear.

To establish the relative contributions of $\mathrm{CRH}$ derived from immune cells versus nervous tissues in PG-APS induced arthritis, Crofford et al ${ }^{12}$ treated rats with dexamethasone. Discordant effects of treatment on synovial CRH production and mononuclear cell infiltration and early increases in $\mathrm{CRH}$ staining prior to cellular infiltration suggested that the nervous system may contribute to the increased $\mathrm{CRH}$ concentrations in inflamed synovium. Similarly, CRH production by the enteric nervous system may contribute to PGAPS induced chronic enterocolitis. Wolter ${ }^{16}$ demonstrated that perikarya and nerve fibres in the myenteric plexus and submucosal nerve fibres of normal rat duodenum contain $\mathrm{CRH}$. We found increased CRH staining in neuronal plexi in the chronically inflamed caecum of Lewis rats. In addition, neuropeptides can be produced by enteric glial cells, which secrete increased amounts of substance $P$ when stimulated by $\mathrm{IL} 1 .^{38} \mathrm{IL1}$ is also a potent stimulus of CRH secretion in the brain ${ }^{39}$ and is considerably increased during chronic PGAPS induced enterocolitis. ${ }^{29}$ Interactions between cytokines and the enteric nervous system may be important in the regulation of $\mathrm{CRH}$ secretion and in the perpetuation of inflammation.

Increased CRH mRNA expression during different phases of chronic granulomatous enterocolitis clearly demonstrates local 
production rather than transport of preformed $\mathrm{CRH}$ from remote production sites to the intestine. Crofford et al detected CRH mRNA in the synovium of a Lewis rat with adjuvant induced arthritis but results could not be compared with healthy joints because of unsuccessful RNA isolation from control synovium. ${ }^{12}$

A previous report of $\mathrm{CRH}$ gene expression in human colonic inflammation has been difficult to reconcile with the authors' own evidence of increased CRH staining in lamina propria cells by immunohistochemistry. ${ }^{19} 37 \mathrm{CRH}$ mRNA values detected by PCR analysis were higher in normal than in ulcerative colitis mucosa ${ }^{37}$ whereas in situ hybridisation signals were confined to scattered crypt epithelial cells and did not differ among normal and inflamed biopsy specimens. ${ }^{19}{ }^{37}$ In our studies increased ceacal CRH mRNA expression consistently correlated with the development of inflammation and irCRH in tissues as measured either by RIA or immunohistochemistry. Moreover, CRH mRNA values in the chronically inflamed caecum at 29,33 , or 85 days were always high compared with normal and HSA injected control caecum (Fig 3). In most control tissues CRH mRNA were undetectable by RT-PCR, but occasionally we found low constitutive $\mathrm{CRH}$ gene expression in normal and HSA injected caecal control samples, consistent with the constitutive CRH peptide values in control tissues as measured by RIA (Fig 2).

The in vitro LPMC response to $\mathrm{CRH}$ further supports the hypothesis that locally produced CRH has an immunomodulatory role in intestinal inflammation. In preliminary studies we found that $\mathrm{CRH}$ regulates proliferation of splenocytes and LPMC as well as cytokine production. ${ }^{40}$ The opposite effect of $\mathrm{CRH}$ on spontaneous and mitogen induced proliferation is of unclear significance. Immune cell responses to neuropeptide stimulation depend on their activation state, for example, intracellular second messenger levels. Moreover, ConA is a non-specific stimulus and may not appropriately reproduce the in vivo immunophysiological activation state of LPMC in PG-APS induced enterocolitis. These results however are consistent with other studies describing stimulatory effects of $\mathrm{CRH}$ on cytokine secretion, IL2 receptor expression, reactive oxygen metabolite production by macrophages, lymphocyte proliferation, and natural killer cell activity. ${ }^{22-28}$ Of relevance to this study, the lymphoproliferative effect of $\mathrm{CRH}$ is higher in B lymphocytes from gut associated lymphoid tissue than in peripheral B cells. ${ }^{27}$ Only a few reports indicate suppressive effects of CRH on IL6 secretion and mitogen induced antibody production. ${ }^{41} 42$ These findings in conjunction with studies showing CRH synthesis by immune cells, ${ }^{43-44}$ high affinity receptors for $\mathrm{CRH}$ on macrophages, $\mathrm{T}$ and $B$ lymphocytes, ${ }^{45-48}$ and autoreactive $T$ cell responses against $\mathrm{CRH},{ }^{47}$ support the concept of a local immunomodulatory role for $\mathrm{CRH}$ in inflammation.

In summary, our data show increased intestinal CRH mRNA expression and tissue concentrations in chronic experimental colitis suggesting a role for CRH in intestinal inflammation. More detailed in vitro studies with isolated mucosal immune cells will provide further insight into the immunostimulatory activities of locally produced $\mathrm{CRH}$ and its contribution to chronic disease in genetically susceptible hosts.

The authors appreciate the technical support of Lisa Holt, Diane Bender, Pat Magyar, Roger Brown, Gloria Chandler, and Joseph Price and editorial comments by Dr Rance Sellon. This work is supported by grants from the Crohn's and Colitis Foundation of America and The National Institutes of Health DK 40249, DK 34987, and DE 10489.

1 Goetzl EJ, Sreedharan SP. Mediators of communication and adaptation in the neuroendocrine and immune systems. FASEB f 1992; 6: 2646-52.

2 Johnson HM, Downs MO, Pontzer CH. Neuroendocrine peptide hormone regulation of immunity. Chem Immunol 1992; 52: 49-83.

3 Blalock JE. The syntax of immune-neuroendocrine communication. Immunol Today 1994; 15: 504-11.

4 Felten DL, Felten SY, Bellinger DL, Carlson SL Ackerman KD, Madden KS, et al. Noradrenergic sympathetic neural interactions with the immune system:
structure and function. Immunol Rev 1987; 100: 225-60.

5 Bellinger DL, Lorton D, Romano TD, Olschowka JA, Felten SY, Felten DL. Neuropeptide innervation of

6 Stead RH, Tomioka M, Quinonez G, Simon GT, Felten SY, Bienenstock J. Intestinal mucosal mast cell in normal and nematode-infected rat intestines are in intimate contact with peptidergic nerves. Proc Natl Acad Sci 1987; 84: 2975-9.

7 Carr DJJ. Neuroendocrine peptide receptors on cells of the immune system. Chem Immunol 1992; 52: 84-105.

8 Stanisz AM, Befus D, Bienenstock J. Differential effects of vasoactive intestinal peptide, substance $P$, and somatostatin on immunoglobulin synthesis and proliferation by lymphocytes from Peyer's patches, mesenteric lymph nodes, and spleen. F Immunol 1986; 136: 152-6.

9 van Tol EAF, Verspaget HM, Hansen BE, Lamers CBHW. Neuroenteric peptides affect natural killer activity by intestinal lamina propria mononuclear cells. $\mathcal{J}$ intestinal lamina propria mon

10 Blalock JE. Production of peptide hormones and neurotransmitters by the immune system. Chem Immunol 1992; 52: 1-24.

11 Karalis K, Sano H, Redwine J, Listwak S, Wilder RL, Chrousos GP. Autocrine or paracrine inflammatory actions of corticotropin-releasing hormone in vivo. Science 1991; 254: 421-3.

12 Crofford LJ, Sano H, Karalis K, Webster EL, Goldmuntz EA, Chrousos GP, et al. Local secretion of corticotropinreleasing hormone in the joints of Lewis rats with

13 Crofford LJ, Sano H, Karalis K, Friedman TC, Epps HR, Remmers EF, et al. Corticotropin-releasing hormone in synovial fluids and tissues of patients with rheumatoid arthritis and osteoarthritis. $\mathcal{f}$ Immunol 1993; 151: 1587-96.

14 Nieuwenhuijzen Kruseman AC, Linton EA, Lowry PJ, Rees LH, Besser GM. Corticotropin-releasing factor immunoreactivity in human gastrointestinal tract. Lancet 1982; ii: 1245-6.

15 Petrusz P, Merchanthaler I, Maderdrut JL, Vigh S, Schally AV. Corticotropin-releasing factor-like Proc Natl Acad Sci 1983; 80: 1721-5.

16 Wolter HJ. Corticotropin-releasing factor is contained within perikarya and nerve fibers of rat duodenum. within perikarya and nerve fibers of rat duode
Biochem Biophys Res Commun 1984; 122: 381-7.

17 Suda T, Tomori N, Tozawa F, Mouri T, Demura H, Shizume K. Distribution and characterization of immunoreactive corticotropin-releasing factor in human tissues. F Clin Endocrinol Metab 1984; 59: 861-6.

18 Petrusz P, Merchanthaler I, Maderdrut JL, Heitz PU. Central and peripheral distribution of cortocotropinreleasing factor. Fed Proc 1985; 44: 229-35.

19 Kawahito Y, Sano H, Kawata M, Yuri K, Mukai S, Yamamura $\mathrm{Y}$, et al. Local secretion of corticotropin releasing hormone by enterochromaffin cells in human colon. Gastroenterology 1994; 106: 859-65.

20 Grino M, Chrousos GP, Margioris AN. The corticotropin releasing hormone gene is expressed in human placenta. releasing hormone gene is expressed in human placer
Biochem Biophys Res Commun 1987; 148: 1208-14.

21 Mastorakos G, Scopa CD, Vryonidou A, Friedman TC, Kattis D, Phenekos C, et al. Presence of immunoreactive Kattis D, Phenekos C, et al. Presence of immunoreactive
corticotropin-releasing hormone in normal and polycystic human ovaries. I Clin Endocrinol Metab 1994; 79: 1191-7.

22 Singh VK, Leu SJC. Enhancing effect of corticotropinreleasing neurohormone on the production of interleukin1 and interleukin-2. Neuroscience 1990; 120: 151-4.

23 Leu SJC, Singh VK. Stimulation of interleukin-6 production by corticotropin-releasing factor. Cell Immunol 1992; 143: 220-7. 
24 Angioni S, Petraglia F, Gallinelli A, Cossarizza A, Franceshi C, Muscettola M, et al. Corticotropin-releasing hormone modulates cytokine release in cultured human peripheral blood mononuclear cells. Life Sci 1993; 53: peripheral

25 Singh VK. Stimulatory effect of corticotropin-releasing neurohormone on lymphocyte proliferation and interleukin-2 receptor expression. F Neuroimmunol 1989; 23: $257-62$.

26 Koshida H, Kotake Y. Corticotropin-releasing hormone enhances the superoxide anion production of rabbit peritoneal macrophages stimulated with $\mathrm{N}$-formyl-methionylleucyl-phenylalanine. Life Sci 1994; 54: 539-43.

27 McGillis JP, Park A, Rubin-Fletter P, Turck C, Dallman MF, Payan DG. Stimulation of rat B-lymphocyte proliferation by corticotropin-releasing factor. Neurosc Res 1989; 23: $346-52$.

28 Leu SJC, Singh VK. Modulation of natural killer cellmediated lysis by corticotropin-releasing hormone. $\mathcal{F}$ mediated lysis by corticotropin

29 McCall RD, Haskill S, Zimmermann EM, Lund PK, Thompson RC, Sartor RB. Tissue interleukin 1 and interleukin-1 receptor antagonist expression in enterocolitis in resistant and susceptible rats. Gastroenterology 1994; 106: 960-72.

30 Sartor RB, Dela Cadena RA, Green KD, Stadnicki A, Davis SW, Schwab JH, et al. Selective kallikrein-kinin system activation in inbred rats differentially susceptible to granulomatous enterocolitis. Gastroenterology 1996; 110: $1467-81$.

31 Sternberg EM, Scott Young W, Bernardini R, Calogero AE, Chrousos GP, Gold PW, et al. A central nervous system defect in biosynthesis of corticotropin-releasing hormone is associated with susceptibility to streptococcal cell wallinduced arthritis in Lewis rats. Proc Natl Acad Sci 1989; induced arthrit $4771-5$.

32 Sternberg EM, Hill JM, Chrousos GP, Kamilaris T, Listwak SJ, Gold PW, et al. Inflammatory mediatorinduced hypothalamic-pituitary-adrenal axis activation is defective in streptococcal cell wall arthritissusceptible Lewis rats. Proc Natl Acad Sci 1989; 86: $2374-8$.

33 Calogero AE, Sternberg EM, Bagdy G, Smith C, Bernardini R, Aksentijevich S, et al. Neurotransmitterinduced hypothalamic-pituitary-adrenal axis responsiveness is defective in inflammatory disease-susceptible Lewis rats: in vivo and in vitro studies suggesting globally defective hypothalamic secretion of corticotropin-releasing hormone. Neuroendocrinology 1992; 55: tropin-rele

34 Stimpson SA, Brown RR, Anderle SK, Klapper DG, Clark RL, Cromartie WJ, et al. Arthropathic properties of cell wall polymers from normal flora bacteria. Infect Immun 1986; 51: 240-9.
35 Dische A, Shettles LR. A specific color reaction of methyl pentoses and a spectrophotometric micromethod for their determination. $\mathcal{F}$ Biol Chem 1948; 175: 595-603.

36 Yamauchi M, Katz EP, Mechanic GL. Intermolecular crosslinking and stereospecific molecular packing in type I collagen fibrils of the periodontal ligament. Biochemistry collagen fibrils of the

37 Kawahito Y, Sano H, Mukai S, Asai K, Kimura S, Yamamura Y, et al. Corticotropin releasing hormone in colonic mucosa in patients with ulcerative colitis. Gut 1995; 37: 544-51.

38 Hurst SM, Stanisz AM, Sharkey KA, Collins SM. Interleukin 1 beta-induced increase in substance $P$ in rat myenteric plexus. Gastroenterology 1993; 105: 1754-60.

39 Sapolsky R, Rivier C, Yamamoto G, Plotsky P, Vale W. Interleukin-1 stimulates the secretion of hypothalamic corticotropin-releasing factor. Science 1987; 238: 522-4.

40 van Tol EAF, Holt L, Bender D, Magyar P, Petrusz P, Yamauchi $\mathrm{M}$, et al. Potential immunomodulatory effects of corticotropin releasing hormone (CRH) in experimental entercolitis. Clin Immunol Immunopathol 1995; 76: S46.

41 Hagan $P$, Poole $S$, Bristow AF. Immunosuppressive activity of corticotropin-releasing factor. $\mathcal{F}$ Biochem 1992; 281: 251-4

42 Leu SJC, Singh VK. Suppression of in vitro antibody production by corticotropin-releasing factor neurohormone. I Neuroimmunol 1993; 45: 23-30

43 Stephanou A, Jessop DS, Knight RA, Lightman SL. Corticotropin-releasing factor-like immunoreactivity and mRNA in human leukocytes. Brain Behav Immun 1990; 4: 67-73.

44 Ekman R, Servenius B, Castro MG, Lowry PJ, Cederlund AS, Bergman $\mathrm{O}$, et al. Biosynthesis of corticotropin-releasing hormone in human T-lymphocorticotropin-releasing hormone in 1 Neuroimmunol 1993; 44: 7-14.

45 Kravchenko IV, Furalev VA. Secretion of immunoreactive corticotropin releasing factor and adrenocorticotropic hormone by T-and B-lymphocytes in response to cellular stress factor. Biochem Biophys Res Commun 1994; 204: 828-34.

46 Webster EL, Tracey DE, Jutila MA, Wolfe SA, De Souza EB. Corticotropin-releasing factor receptors in mouse spleen: identification of receptor-bearing cells as resident macrophages. Endocrinology 1990; 127: 440-52.

47 Griffin AC, Zhao W, Wegmann KW, Hickey WF. The T-cell reptertoire contains cells reactive with hormones of the hypothalamic-pituitary-adrenal axis: recognition of hypthic synthetic peptide fragments of corticotropin-releasing the Lewis rat. Brain Behav Immun 1994; 8: 313-26.

48 Audhya T, Jain R, Hollander CS. Receptor-mediated immunomodulation by corticotropin-releasing factor. Cell Immunol 1991; 134: 77-84. 